In 1947 the Brookhaven National Laboratory, Upton, New York, after careful consideration of the scientific, economic and practical factors involved, concluded that the proton synchrotron was the best type of accelerator suitable for the purpose, and in 1948, with the financial assistance of the United States Atomic Energy Commission, the design and construction of the cosmotron was commenced. The assembly took nearly four years, and in Mry 1952 a proton beam of $1,000 \mathrm{MeV}$. energy was obtained. This was increased to $2,000 \mathrm{MeV}$. in the following month, and with suitable modifications to the pole windings it is confidently expected that $3,000 \mathrm{MeV}$. will finally be obtained. Machines capable of reaching higher energies are being constructed elsewhere; but the cosmotron was the first high-energy accelerator to be constructed and to be operated.

The work was directed initially by M. Stanley Livingston (Massachusetts Institute of Technology), then by Milton G. White (Princeton University), and finally by G. B. Collins, who is the present chairman and who joined the project in April 1950. A detailed description of the principle, construction and operation of the cosmotron is given in a series of articles, edited by M. Hildred Blewett, a member of the cosmotron staff, in the special cosmotron issue of the Review of Scientific Instruments $(24$, No. 9 ; September 1953). L. J. Haworth, director of the Brookhaven Laboratory, contributes a short foreword, and this is followed by a general review, by the editor, of the cosmotron, discussed component by component and giving data concerning the personnel, cost and basic parameters.

A ring-shaped magnet guides the particles on a circular path of radius $30 \mathrm{ft}$., and $\mathrm{a}$ radiofrequency electric accelerating field provides increments of energy to the protons which are injected initially into the cosmotron, at about $3.5 \mathrm{MeV}$., from a Van de Graaff accelerator. The maximum magnetic field is 14,000 gauss. The vacuum is maintained by twelve 20 -in. diffusion pumps at a minimum operating pressure of $5 \times 10^{-6} \mathrm{~mm}$. of mercury, and the volume evacuated is about $300 \mathrm{cu}$. ft. The other articles in the series are divided into sections dealing with the magnet, the pole-face windings, the radiofrequency system, the injection system, the vacuum system and the control system, respectively. Finally, three short papers desl with the cosmotron building, eddy-current phenomena and studies of injection phenomena in the cosmotron, respectively.

\section{ALEURONE LAYER IN BARLEY}

YN a comprehensive anatomical investigation of the 1 sleurone layer in the cultivated barley, J. Sawicki (Polska Akademia Umiejetnosci, No. 66, 1-59, pub. Krakow, 1952, with English summary) has examined 103 varieties, representing all the sub-species of Hordeum sativum collected in different parts of the world.

In these materials, the number of cell rows in the aleurone layer and its thickness were observed. The range of variability of these characters was studied to see if they could be used in the classification of barleys. The hereditary transmission of these characters was also investigated over a period of several years. It has been ascertained that the varieties examined show distinct differences in regard to both the characteristics studied. The mean number of cell rows in the aleurone layer of the different barley varieties ranges from $1 \cdot 64$ to $3 \cdot 11$, and the mean thickness of the aleurone layer from 49.94 to $110 \cdot 16$ microns.

Observations of the two characteristics in question on material from several years and from different climatic conditions showed that they exhibit $a_{0}$ com. paratively small variability due to the environmental conditions. A detailed analysis of variance of material of forty varieties from 1937, 1938 and 1947 cultures showed that as regards the number of the cell rows the varietal differences are responsible for 93.00 per cent of the total variation and for 85.60 per cent as regards thickness of the aleurone layer. The variation due to seasonal differences is very small : in the first case 0.60 per cent, and in the second 0.40 per cent of the total variation. The remaining amounts of variation are due to unknown causes (environmental changes). Similar results were obtained by analysis of the variation of the pedigree lines from 1947,1948 and 1949, indicating that there are no essential differences between the pedigree lines and the examined material of commercial varieties. The results obtained justify the view that the aleurone characters are comparatively constant and may therefore be used in classification.

It is held that the results of these investigations corroborate the earlier data of Orlow, who found that barleys endemic in the Asiatic centre of origin as a rule possess three rows, and those of the African centre two rows, of cells in the aleurone layer only. As the European varieties of cultivated barley show a similar differentiation, the possibility exists of explaining, in some cases, their primary origin.

\section{FORESTRY COMMISSION IN SCOTLAND}

TN a small illustrated pamphlet entitled "The Forestry Commission in Scotland" (recently published by the Forestry Commission) it is stated that the history of forestry in Scotland is a long one. Shakespeare in "Macbeth", for example, brought the Birnam Woods to Dunsinane, a difficult military position, and timber from the same Birnam Hill in Perthshire was used for helping the national effort during the Second World War. Great natural woods once covered most of Scotland; but through the years, fire, disease and the axe took a great toll. Later, many of the remaining forests were exploited for charcoal for iron-smelting purposes, followed by the spread of sheep-raising at the end of the eighteenth century.

It was the great inroads into the woods of the country, almost entirely privately owned, during the First World War that brought the Forestry Commission under the Forestry Act of 1919. The Commission was reconstituted by the Forestry Acts of 1945 and 1951. Under the 1945 Act the Commission was made subject to direction from the Minister of Agriculture and Fisheries and the Secretary of State for Scotland. In Scotland all land acquired through the Forestry Fund is vested in the Secretary of State.

Between the World Wars a great deal of planting was done by the Forestry Commission, but the resultant plantations were still too young to provide any contribution of value to the timber requirements of the Second World War. Once again it was the 